\title{
KEPEMILIKAN MANAJERIAL, KEPEMILIKAN INSTITUSIONAL, PROFITABILITAS, LEVERAGE, LIKUIDITAS DAN KEBIJAKAN DIVIDEN (Perusahaan Sektor Industri Barang Konsumsi Di Bursa Efek Indonesia)
}

\author{
Oleh \\ Tantri Cahyaning Amalia ${ }^{1)}$, Siti Nurlaela ${ }^{2)}$, Riana Rachmawati Dewi ${ }^{3)}$ \\ Universitas Islam Batik Surakarta \\ tantri.cahya98@gmail.com
}

\begin{abstract}
This study aims to analyze the factors affecting the dividend payment policy which was presented with Dividend Payout Ratio (DPR). The independent variables include managerial ownership, institutional ownership, profitability (Return on Assets), leverage (Debt to Equity Ratio) and liquidity (Current Ratio). This research was conducted in the consumer goods industry companies listed on the Stock Exchange in 2013-2018. The samples used are 9 companies. The sampling method using purposive sampling. Data analysis technique used is multiple linear regression. The results showed that the profitability (Return on Assets) and leverage (Debt to Equity Ratio) have effect on dividend policy. While the managerial ownership, institusional ownership, and liquidity (Current Ratio) that have no effect on dividen policy.
\end{abstract}

Keywords: Ownership, Profitability, Leverage, Liquidity, Dividend.

\section{PENDAHULUAN}

Salah satu masalah utama yang dihadapi oleh perusahaan berkaitan dengan kebijakan dividen. Menurut Haryetti \& Ekayanti (2012) kebijakan dividen merupakan kebijakan untuk menentukan besarnya pendapatan yang dibagikan pada pemegang saham dan bagian laba yang ditahan perusahaan. Kebijakan dividen melibatkan pihak manajemen dan pihak pemegang saham. Adapun tujuan pemegang saham atau investor menanamkan modalnya di perusahaan yaitu untuk mendapatkan pengembalian keuntungan dari dana yang diinvestasikan, sedangkan dari pihak manajemen perusahaan lebih menitikberatkan tujuannya pada peningkatan laba.

Menurut (Taofik, Olabayo, \& Ola, 2018) Struktur kepemilikan dapat mempengaruhi kebijakan dividen. Struktur kepemilikan terdiri dari kepemilikan manajerial dan kepemilikan institusional. Menurut (Alashhab, Jaara, \& Bassam, 2018) profitabilitas merupakan salah satu faktor utama yang mempengaruhi kebijakan dividen suatu perusahaan. Sedangkan menurut (Laily, 2017) faktor yang mempengaruhi kebijakan dividen yaitu leverage. Faktor lain yang mempengaruhi 
kebijakan dividen menurut (Karthik \& Devanadhen, 2015) yaitu likuiditas. Dari latar belakang tersebut rumusan masalah dalam penelitian ini adalah :

1. Apakah kepemilikan manajerial berpengaruh terhadap kebijakan dividen pada perusahaan sektor industri barang konsumsi yang terdaftar di Bursa Efek Indonesia tahun 2013-2018?

2. Apakah kepemilikan institusional berpengaruh terhadap kebijakan dividen pada perusahaan sektor industri barang konsumsi yang terdaftar di Bursa Efek Indonesia tahun 2013-2018?

3. Apakah profitabilitas berpengaruh terhadap kebijakan dividen pada perusahaan sektor industri barang konsumsi yang terdaftar di Bursa Efek Indonesia tahun 2013-2018?

4. Apakah leverage berpengaruh terhadap kebijakan dividen pada perusahaan sektor industri barang konsumsi yang terdaftar di Bursa Efek Indonesia tahun 2013-2018 ?

5. Apakah likuiditas berpengaruh terhadap kebijakan dividen pada perusahaan sektor industri barang konsumsi yang terdaftar di Bursa Efek Indonesia tahun 2013-2018 ?

\section{LANDASAN TEORITIS DAN PENGEMBANGAN HIPOTESIS}

\section{Teori Stakeholder}

Menurut Robbins \& Coulter (2007) Teori stakeholder menyatakan bahwa perusahaan memiliki pihak-pihak yang memiliki kepentingan terhadap perusahaan. Pihak-pihak ini dapat meliputi investor dan non investor seperti pelanggan, karyawan, pemasok, masyarakat sekitar, dan pemerintah. Teori stakeholder menyatakan bahwa perusahaan bukan hanya beroperasi untuk mencari laba yang sebesar-besarnya, tetapi juga harus memberikan manfaat bagi stakeholder-nya.

\section{Kepemilikan Manajerial}

Menurut (Wahidahwati, 2002) kepemilikan saham manajerial adalah persentase kepemilikan saham yang dimiliki oleh manajemen yaitu direksi, manajer dan dewan komisaris yang secara aktif ikut serta dalam pengambilan keputusan perusahaan.

\section{Kepemilikan Institusional}

Menurut (Edison, 2017) kepemilikan institusonal meliputi kepemilikan saham oleh pihak-pihak yang berbentuk institusi seperti yayasan, bank, perusahaan asuransi, perusahaan investasi, perusahaan berbentuk perseroan (PT), dan institusi lainnya. 


\section{Profitabilitas}

Profitabilitas adalah kemampuan perusahaan dalam mencari keuntungan atau laba dalam suatu periode tertentu (Nurlaela dkk, 2019). Apabila tingkat profitabilitas perusahaan tinggi, maka laba yang dihasilkan perusahaan semakin besar dan kemungkinan akan dibagikan dalam bentuk dividen kepada pemegang saham (Kasmir, 2010). Profitabilitas diproksikan dengan return on asset. Return on Asset menunjukkan kemampuan perusahaan dengan menggunakan seluruh aktiva yang dimiliki untuk menghasilkan laba setelah pajak (Sudana, 2011).

\section{Leverage}

Leverage adalah kemampuan perusahaan dalam memenuhi seluruh kewajibannya yang ditunjukan oleh bagian modal sendiri yang digunakan untuk membayar hutang (Kasmir, 2012). Leverage diproksikan dengan debt to equity ratio. Semakin besar rasio debt to equity ratio menunjukkan semakin besar pula beban biaya hutang yang harus dibayar perusahaan. Peningkatan hutang akan mempengaruhi besar kecilnya laba bersih yang tersedia bagi pemegang saham termasuk dividen yang akan diterima (Wedyaningsih, Nurlaela, \& Titisari, 2019).

\section{Likuiditas}

Likuiditas adalah kemampuan perusahaan untuk membayar kewajiban finansial jangka pendek tepat pada waktunya (Winanti, Nurlaela, \& Titisari, 2017). Likuiditas badan usaha dapat diketahui dari neraca pada saat antara lain dengan membandingkan jumlah aktiva lancar (current assets) dengan utang lancar (current liabilities). Hasil perbandingan inilah yang disebut dengan current ratio.

\section{Kebijakan Dividen}

Menurut (Sartono, 2015) kebijakan dividen adalah keputusan apakah laba yang diperoleh perusahaan akan dibagikan kepada pemegang saham sebagai dividen atau akan ditahan dalam bentuk laba ditahan guna pembiayaan investasi dimasa datang. Apabila perusahan memilih untuk membagikan laba sebagai dividen, maka akan mengurangi laba yang akan digunakan untuk kegiatan pembiayaan perusahaan.

\section{Hipotesis}

Penelitian yang dilakukan oleh Taofik, Olabayo, \& Ola (2018) menunjukkan bahwa kepemilikan manajerial berpengaruh terhadap kebijakan dividen di Nigeria. Hal ini disebabkan karena semakin banyaknya saham yang dimiliki oleh pemegang 
saham atau pihak manajemen (direktur dan komisaris) maka pihak manajemen akan semakin berkeinginan untuk membagikan dividen dalam jumlah yang besar. Karena akan menguntungkan juga untuk dirinya sendiri

\section{H1: Kepemilikan Manajerial berpengaruh terhadap Kebijakan Dividen}

Penelitian yang dilakukan oleh (Kautsar, 2019) menunjukkan bahwa kepemilikan institusional berpengaruh terhadap kebijakan dividen. Investor institusional sebagai pemegang saham lebih menyukai perusahaan membagikan labanya dalam bentuk dividen.

\section{H2 : Kepemilikan Institusional berpengaruh terhadap Kebijakan Dividen}

Penelitian oleh Alashhab, Jaara, \& Bassam, (2018) dan (Wahyuni \& Hafiz, 2018) menunjukkan bahwa profitabilitas berpengaruh terhadap pembayaran dividen. Perusahaan dengan profitabilitas tinggi akan membayar dividen yang lebih besar.

\section{H3 : Profitabilitas berpengaruh terhadap Kebijakan Dividen}

Dalam penelitian (Laily, 2017), (Cahyanti, 2018) menyatakan bahwa leverage berpengaruh terhadap kebijakan dividen. Apabila utang meningkat akan memberikan pengaruh semakin rendahnya kemampuan perusahaan dalam membayar dividen. sebaliknya jika perusahaan memiliki utang yang sedikit makan kemungkinan perusahaan dalam membayar dividen akan tinggi.

\section{H4 : Leverage berpengaruh terhadap Kebijakan Dividen}

Penelitian terdahulu yang dilakukan oleh (Lestari, Tanuatmodjo, \& Mayasari, 2016) serta (Sholikhah \& Hermanto, 2017) yang memperoleh hasil bahwa likuiditas yang diproksikan dengan current ratio berpengaruh terhadap kebijakan dividen.

\section{H5 : Likuiditas berpengaruh terhadap Kebijakan Dividen}

\section{METODE PENELITIAN}

Jenis Penelitian ini menggunakan jenis data kuantitatif. Dalam penelitian ini data yang digunakan adalah data sekunder. Teknik pengambilan data yaitu dokumentasi. Pengujian data dilakukan dengan menggunakan analisis uji regresi linier berganda. Populasi dalam penelitian ini adalah perusahaan industri barang konsumsi yang terdaftar di Bursa Efek Indonesia (BEI) tahun 2013-2018. Sampel dipilih dengan menggunakan metode purposive sampling, dengan kriteria sebagai berikut: (1) Perusahaan yang menyampaikan laporan keuangannya dalam mata uang rupiah (2) Perusahaan Industri Barang Konsumsi di BEI yang mempublikasikan laporan 
keuangan tahunan secara konsisten pada tahun 2013-2018.(3) Perusahaan yang menyampaikan datanya secara lengkap sesuai dengan informasi yang diperlukan, yaitu kepemilikan manajerial, kepemilikan institusional, return on asset, debt to equity ratio dan current ratio. (4) Perusahaan yang membagikan dividen secara berturut-turut selama enam tahun penelitian dari tahun 2013-2018.

\section{HASIL DAN PEMBAHASAN}

Statistik deskriptif digunakan untuk mengetahui karakteristik data dengan menggunakan nilai maksimum, nilai minimum, mean, dan standar devisiasi dari seluruh data variabel. Berikut hasil uji statistik deskriptik dalam penelitian ini :

Tabel 1

Hasil uji Statistik Deskripstif

\begin{tabular}{lccccc}
\hline & N & Min & Max & Mean & Std. deviation \\
\hline Kebijakan dividen (Y) & 54 & 0,1514 & 0,9987 & 0,4280 & 0,2194 \\
Kepemilikan manajerial (X1) & 54 & 0,0000 & 0,2522 & 0,0165 & 0,0581 \\
& & & & & \\
Kepemilikan institusional (X؛ 54 & 0,0004 & 0,9626 & 0,6987 & 0,2135 \\
& & & & & \\
Profitabilitas (X3) & 54 & 0,0295 & 0,4666 & 0,1242 & 0,1085 \\
Leverage (X4) & 54 & 0,0687 & 2,6546 & 0,9170 & 0,6357 \\
Likuiditas (X5) & 54 & 0,6056 & 5,7591 & 2,2800 & 1,2653 \\
Valid N (listwise) & 54 & & & & \\
\hline
\end{tabular}

Hasil statistik deskriptif pada tabel 1 diatas menunjukan bahwa variabel kebijakan dividen nilai minimum sebesar 0,1514 nilai maksimum 0,9987 nilai ratarata (mean) sebesar 0,4280 dan nilai standar deviasi sebesar 0,2194. Variabel kepemilikan manajerial nilai minimum sebesar 0,0000 nilai maksimum 0,2522 nilai rata-rata (mean) sebesar 0,0165 dan nilai standar deviasi sebesar 0,0581. Variabel kepemilikan institusional nilai minimum sebesar 0,0004 nilai maksimum 0,9626 nilai rata-rata (mean) sebesar 0,6987 dan nilai standar deviasi sebesar 0, 2135. Variabel profitabilitas nilai minimum sebesar 0,0295 nilai maksimum 0,4666 nilai rata-rata (mean) sebesar 0,1242 dan nilai standar deviasi sebesar 0,1085. Variabel leverage nilai minimum sebesar 0, 0687 nilai maksimum 2,6546 nilai rata-rata (mean) sebesar 0,9170 dan nilai standar deviasi sebesar 0,6357. Variabel likuiditas nilai minimum 
sebesar 0,6056 nilai maksimum 5,7591 nilai rata-rata (mean) sebesar 2,2800 dan nilai standar deviasi sebesar 1,2653.

\section{Uji Asumsi Klasik}

Uji Normalitas

Uji normalitas bertujuan untuk menguji apakah dalam model regresi, variabel pengganggu atau residual memiliki distribusi normal atau tidak. Uji normalitas yang digunakan dalam penelitian ini adalah Kolmogorov-Sminorv. Hasil uji normalitas dapat dilihat pada tabel :

Tabel 2

Hasil Uji Normalitas

\begin{tabular}{llll}
\hline Variabel & Sig & Standar & Ket. \\
\hline $\begin{array}{l}\text { Unstandardized } \\
\text { Residual }\end{array}$ & 0,200 & 0,05 & Data \\
& & & terdistribusi \\
& & & Normal \\
\hline
\end{tabular}

Berdasarkan hasil uji normalitas dengan menggunakan One-Sampel KolmogorovSmirnov Test, dapat dilihat nilai signifikannya adalah $0,200>0,05$ maka hasilnya adalah normal.

\section{Uji Autokorelasi}

Uji autokorelasi digunakan untuk mengetahui ada atau tidaknya penyimpangan asumsi klasik autokorelasi yaitu korelasi yang terjadi antara residual pada satu pengamatan dengan pengamatan lain pada model regresi. Model regresi yang digunakan adalah uji Durbin Watson (DW-test). Kriteria yang digunakan adalah sebagai berikut : (1) Jika DW < dL atau DW > 4-dL berarti terjadi autokorelasi (2) Jika DW terletak antara dU dan 4-dU, berarti tidak terjadi autokorelasi (3) Jika DW terletak antara dL dan dU atau diantara (4-dU) dan (4-dL), maka tidak menghasilkan kesimpulan yang pasti.

Tabel 3

Hasi Uji Autokorelasi

\begin{tabular}{llllll}
\hline $\begin{array}{l}\text { Durbin } \\
\text { Watson }\end{array}$ & $\mathrm{dL}$ & $\mathrm{dU}$ & 4-dL & $4-\mathrm{du}$ & Kesimpulan \\
\hline 1.858 & 1,366 & 1,768 & 2,633 & 2,142 & $\begin{array}{l}\text { Tidak terjadi } \\
\text { autokorelasi }\end{array}$ \\
\hline
\end{tabular}


Berdasarkan tabel 3 di atas dapat dilihat dari DW adalah 1,858. Untuk nilai dL dan dU dapat dilihat dari DW tabel pada signifikansi 0,05 dengan $\mathrm{n}$ (jumlah data) $=54$ dan $\mathrm{k}$ (jumlah variabel independen) $=5$ didapatkan nilai $\mathrm{dL}$ adalah 1,3669 dan nilai dU adalah 1,7684. Jadi nilai 4-dL =2,6331 dan 4-dU =2,142. Hal ini berarti nilai DW 1,858 terletak antara $\mathrm{dU}=1,7684$ dan $4-\mathrm{dU}=2,142$, maka dapat disimpulkan bahwa tidak terjadi autokorelasi.

Uji Multikolinieritas

Untuk melihat ada atau tidaknya multikolinearitas maka dilakukan dengan melihat nilai tolerance dan lawannya Variance Inflation Factor (VIF). Apabila nilai VIF $<10$ dan nilai tolerance $>0,1$ maka tidak terjadi multikolinearitas antar variabel independennya. Hasil uji multikolinieritas dapat dilihat pada tabel dibawah ini :

Tabel 4

Hasil Uji Multikolinieritas

\begin{tabular}{cccccl}
\hline Variabel & Tolerance & Std & VIF & Std & Keterangan \\
\hline $\begin{array}{c}\text { Kepemilikan } \\
\text { Manajerial }\end{array}$ & 0,981 & 0,1 & 1,019 & 10 & $\begin{array}{l}\text { Tidak terjadi } \\
\text { multikolineritas }\end{array}$ \\
$\begin{array}{c}\text { Kepemilikan } \\
\text { Institusional }\end{array}$ & 0,924 & 0,1 & 1,082 & 10 & $\begin{array}{l}\text { Tidak terjadi } \\
\text { multikolineritas }\end{array}$ \\
Profitabilitas & 0,672 & 0,1 & 1,487 & 10 & $\begin{array}{l}\text { Tidak terjadi } \\
\text { multikolineritas }\end{array}$ \\
Leverage & 0,424 & 0,1 & 2,356 & 10 & $\begin{array}{l}\text { Tidak terjadi } \\
\text { multikolineritas }\end{array}$ \\
Likuiditas & 0,551 & 0,1 & 1,816 & 10 & $\begin{array}{l}\text { Tidak terjadi } \\
\text { multikolineritas }\end{array}$ \\
\hline
\end{tabular}

Berdasarkan tabel 1.4 dapat diketahui bahwa dalam penelitaian ini semua variabel tidak terjadi multikolinieritas. Hal ini dapat ditunjukkan dengan nilai tolerance lebih besar dari standard dan nilai VIF lebih kecil dari standar.

Uji Heteroskedastisitas

Uji heteroskedastisitas bertujuan menguji apakah model regresi terjadi ketidaksamaan variance dari residual suatu pengamatan ke pengamatan lainnya. Metode yang digunakan untuk menguji heteroskedastisitas adalah mebuat grafik plot. Hasil uji heteroskedastisitas dapat dilihat pada gambar dibawah ini : 


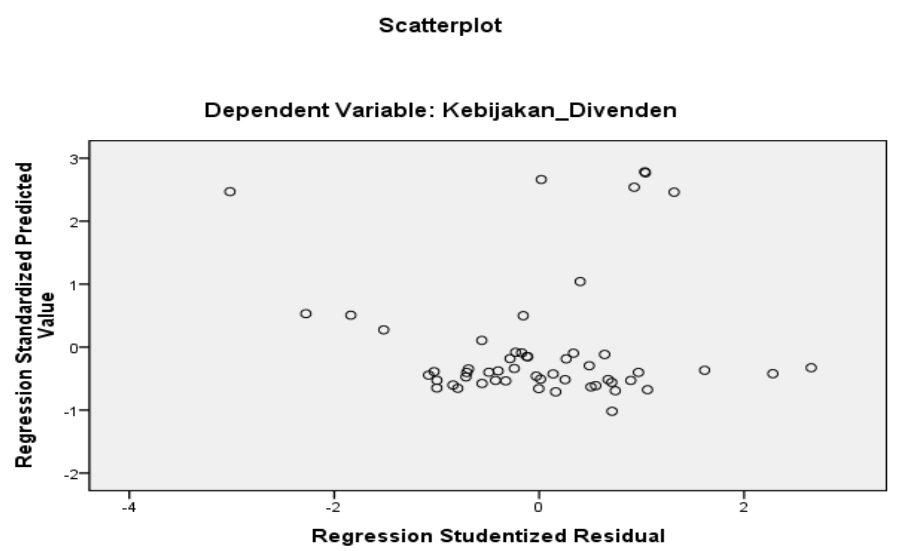

Berdasarkan gambar diatas dengan menggunakan scatterplot terlihat bahwa titiktitik menyebar secara acak serta tersebar secara baik diatas maupun dibawah 0 pada sumbu Y. Hal ini dapat disimpulkan bahwa sebaran titik-titik dinyatakan tidak terjadi heteroskedastisitas pada model regresi.

\section{Uji Regresi Linier Berganda}

Analisis ini digunakan untuk mengetahui pengaruh antara kepemilikan manajerial, kepemilikan institusional, profitabilitas, leverage dan likuiditas terhadap kebijakan dividen. Perhitungan analisis regresi linier berganda dilakukan dengan menggunakan software SPSS 22 yang disajikan sebagai berikut :

Tabel 5

\section{Hasil Uji Regresi}

\begin{tabular}{lc}
\hline \multicolumn{1}{c}{ Model } & $\begin{array}{c}\text { Unstandardized } \\
\text { Coefficients } \\
\text { B }\end{array}$ \\
\hline (Constant) & 0,201 \\
Kepemilikan_Manajerial & $-0,228$ \\
Kepemilikan_Institusional & $-0,040$ \\
Profitabilitas & 0,894 \\
Leverage & 0,124 \\
Likuiditas & 0,015 \\
\hline
\end{tabular}

Berdasarkan tabel diatas maka diperoleh regresi linier berganda pada penelitian ini sebagai berikut : $\mathrm{Y}=0,201-0,228 \mathrm{KM}-0,040 \mathrm{KI}+0,894 \mathrm{PRF}+0,124 \mathrm{LEV}+$ 0,015LIK. Arti dari angka-angka tersebut :

a. Nilai konstanta $(\alpha)$ adalah 0,201. Artinya jika Kepemilikan Manajerial, Kepemilikan Institusional, Profitabilitas, Leverage dan Likuiditas bernilai 0, maka 
kebijakan dividen akan bernilai tetap 0,201.

b. Nilai koefisien regresi variabel kepemilikan manajerial bernilai negatif, yaitu 0,228 ; artinya setiap peningkatan kepemilikan manajerial sebesar 1 satuan maka akan menurunkan kebijakan dividen sebesar -0,228.

c. Nilai koefisien regresi variabel kepemilikan institusional bernilai negatif, yaitu 0,040; artinya setiap peningkatan kepemilikan institusional sebesar 1 satuan maka akan menurunkan kebijakan dividen sebesar -0,040.

d. Nilai koefisien regresi variabel profitabilitas bernilai positif, yaitu 0,894; artinya setiap peningkatan profitabilitas sebesar 1 satuan maka akan meningkatkan kebijakan dividen sebesar 0,894 .

e. Nilai koefisien regresi variabel leverage bernilai positif, yaitu 0,124; artinya setiap peningkatan leverage sebesar 1 satuan maka akan meningkatkan kebijakan dividen sebesar 0,124 .

f. Nilai koefisien regresi variabel likuiditas bernilai positif, yaitu 0,015 ; artinya setiap peningkatan likuiditas sebesar 1 satuan maka akan meningkatkan kebijakan dividen sebesar 0,015 .

\section{Pengujian Hipotesis}

Uji ini mengukur apakah semua variabel independen yang ada pada penelitian mempunyai pengaruh secara bersama (simultan) terhadap variabel dependen. Pada derajat 5\% hipotesis alternative diterima dan semua variabel independen secara signifikan mempengaruhi variabel dependen. Hasil uji $\mathrm{F}$ dapat dilihat pada tabel berikut

Tabel 6

Hasil Uji F

\begin{tabular}{llllc}
\hline $\begin{array}{l}\mathrm{F} \\
\text { hitung }\end{array}$ & $\begin{array}{l}\mathrm{F} \\
\text { tabel }\end{array}$ & Sig & Standar & Hasil \\
\hline 7,794 & 2,409 & 0,000 & 0,05 & $\begin{array}{l}\text { Berpengaruh } \\
\text { Simultan }\end{array}$ \\
\hline
\end{tabular}

Hasil pengujian menunjukkan bahwa nilai F hitung sebesar 7,749. Sedangkan nilai $F$ tabel pada tingkat signifikansi 0,05 dengan df $1=5$ dan df $2=48$ yaitu 2,409 $(7,749>2,409)$ dan signifikansi $(0,000<0,05)$ sehingga dapat disimpulkan bahwa kepemilikan manajerial, kepemilikan institusional, profitabilitas, leverage, dan likuiditas secara simultan berpengaruh terhadap kebijakan dividen. 
Tabel 7

Hasil Uji t

\begin{tabular}{llllll}
\hline Hipotesis & $\mathrm{t}_{\text {hitung }}$ & $\mathrm{t}_{\text {tabel }}$ & $\mathrm{Sig}$ & Standar & Ket. \\
\hline H1 & $-0,559$ & 2,010 & 0,579 & 0,05 & Ditolak \\
H2 & $-0,350$ & 2,010 & 0,728 & 0,05 & Ditolak \\
H3 & 3,384 & 2,010 & 0,001 & 0,05 & Diterima \\
H4 & 2,186 & 2,010 & 0,034 & 0,05 & Diterima \\
H5 & 0,599 & 2,010 & 0,552 & 0,05 & Ditolak \\
\hline
\end{tabular}

Dari tabel diatas dapat diketahui hipotesis 1 ditolak karena $t_{\text {hitung }}<t_{\text {tabel }}(-0,559<$ 2,010) dan sig > 0,05 $(0,579>0,05)$ menunjukan bahwa kepemilikan manajerial tidak berpengaruh terhadap kebijakan dividen. hipotesis kedua ditolak karena $t_{\text {hitung }}<$ $\mathrm{t}_{\text {tabel }}(-0,350<2,010)$ dan sig $>0,05(0,728>0,05)$ menujukan bahwa kepemilikan institusional tidak berepngaruh terhadap kebijakan dividen. dan untuk hipotesis 3 diterima karena $t_{\text {hitung }}>t_{\text {tabel }}(3,384>2,010)$ dan sig $<0,05(0,001<0,05)$ menujukan bahwa profitabilitas berpengaruh terhadap kebijakan dividen. hipotesis 4 diterima $t_{\text {hitung }}>\mathrm{t}_{\text {tabel }}(2,186>2,010)$ dan sig $<0,05(0,034<0,05)$ menujukan bahwa leverage berpengaruh terhadap kebijakan dividen. sedangkan untuk hipotesis 5 ditolak karena $\mathrm{t}_{\text {hitung }}<\mathrm{t}_{\text {tabel }}(0,599<2,010)$ dan sig $>0,05(0,552>0,05)$ menjukan bahwa likuiditas tidak berpengaruh terhadap kebijakan dividen. Nilai koefisien determinasi $\left(\mathrm{R}^{2}\right)$ sebesar 0,391 sehingga dapat diketahui bahwa variabel dependen dalam ini kebijakan dividen dapat dipengaruhi sebesar $39,1 \%$ oleh variabel independen. Sedangkan 60,9\% variabel dependen kebijakan dividen dipengaruhi oleh variabel independen lain yang tidak dimasukkan dalam penelitian ini.

\section{Pembahasan}

a. Kepemilikan manajerial tidak berpengaruh terhadap kebijakan dividen. Berdasarkan pengujian hipotesis yang sudah dilakukan, hasilnya diperoleh nilai signifikansi kepemilikan manajerial sebesar 0,579 yang berarti lebih besar dari 0,05 dengan demikian dapat disimpulkan bahwa kepemilikan manajerial tidak berpengaruh terhadap kebijakan dividen. Hal ini tidak sejalan dengan penelitian Taofik, Olabayo, \& Ola, (2018) dan Al-Qahtani \& Ajina (2017). Kepemilikan manajerial tidak berperngaruh terhadap kebijakan dividen disebabkan karena sampel perusahaan yang diteliti oleh peneliti memiliki tingkat presentase kepemilikan manajerial yang rendah atau saham yang dimiliki 
oleh manajemen masih merupakan saham minoritas dibandingkan kelompok lainya dalam perusahaan, sehingga kepemilikan manajerial tidak berpengaruh dalam pengambilan keputusan pembayaran dividen. Hal ini sejalan dengan penelitian Ridho (2015), yang menyatakan bahwa kepemilikan manajerial tidak berpengaruh terhadap kebijakan dividen.

b. Kepemilikan institusional tidak berpengaruh terhadap kebijakan dividen. Berdasarkan pengujian hipotesis yang sudah dilakukan, hasilnya diperoleh nilai signifikansi kepemilikan institusional sebesar 0,728 yang berarti lebih besar dari 0,05 dengan demikian dapat disimpulkan bahwa kepemilikan institusional tidak berpengaruh terhadap kebijakan dividen. Kepemilikan institusional tidak berpengaruh terhadap kebijakan dividen diduga karena investor institusional memiliki keinginan yang berbeda dengan keinginan investor umum. Tujuan investasi mereka secara umum berjangka panjang, sehingga mereka lebih menyukai perusahaan menginvestasikan kembali labanya daripada perusahaan membagikan sebagian laban untuk dividen. Hasil penelitian ini didukung oleh Djumahir (2011) yang menyatakan bahwa kepemilikan institusional tidak berpengaruh terhadap kebijakan dividen.

c. Profitabilitas berpengaruh terhadap kebijakan dividen. Berdasarkan pengujian hipotesis yang sudah dilakukan, hasilnya diperoleh nilai signifikansi profitabilitas sebesar 0,001 yang berarti lebih kecil dari 0,05 dengan demikian dapat disimpulkan bahwa profitabilitas berpengaruh terhadap kebijakan dividen. Hal ini sejalan dengan penelitian Alashhab, Jaara, \& Bassam, (2018), Ginting (2018) dan Susmitha (2015). Perusahaan yang memiliki tingkat profitabilitas yang tinggi akan membagikan dividen yang tinggi pula kepada para pemegang saham, dikarenakan perusahaan dapat mengolah asetnya dengan efektif sehingga menghasilkan pendapatan yang lebih tinggi dan memberikan sebagian dari pendapatan itu kepada pemegang saham.

d. Leverage berpengaruh terhadap kebijakan dividen. Berdasarkan pengujian hipotesis yang sudah dilakukan, hasilnya diperoleh nilai signifikansi leverage sebesar 0,034 yang berarti lebih kecil dari 0,05 dengan demikian dapat disimpulkan bahwa leverage berpengaruh terhadap kebijakan dividen. Hal ini sejalan dengan penelitian Laily (2017) dan Cahyanti (2018). Semakin rendah leverage maka semakin besar kemampuan perusahaan untuk membagikan dividen. Karena perusahaan tidak memiliki kewajiban membayar hutang yang besar sehingga laba yang diperoleh bisa untuk membagikan dividen kepada pemegang saham.

e. Likuiditas tidak berpengaruh terhadap kebijakan dividen. Berdasarkan pengujian hipotesis yang sudah dilakukan, hasilnya diperoleh nilai signifikansi leverage 
sebesar 0,552 yang berarti lebih besar dari 0,05 dengan demikian dapat disimpulkan bahwa likuiditas tidak berpengaruh terhadap kebijakan dividen. Likuiditas tidak berpengaruh terhadap kebijakan dividen disebabkan karena sampel yang diteliti merupakan perusahaan yang memiliki likuiditas tinggi menandakan bahwa kas yang dimiliki cukup banyak. Tetapi kas yang banyak tersebut tidak digunakan untuk membagikan dividen melainkan akan digunakan perusahaan untuk melakukan investasi yang menguntungkan kepentingan sendiri. Penelitian ini didukung oleh Ginting (2018) yang menjelaskan bahwa likuiditas tidak berpengaruh terhadap kebijakan dividen.

\section{KESIMPULAN}

Penelitian ini bertujuan untuk mengetahui apakah ada pengaruh kepemilikan manajerial, kepemilikan institusional, profitabilitas, leverage dan likuiditas terhadap kebijakan dividen yang dilakukan pada perusahaan industri barang konsumsi yang terdaftar di Bursa Efek Indonesia tahun 2013-2018. Metode pengambilan sampel menggunakan purposive sampling dan didapatkan sampel sebanyak 9 perusahaan yang sesuai dengan kriteria penelitian. Metode analisis data yang digunakan dalam penelitian ini adalah uji regresi linier berganda. Berdasarkan hasil penelitian diperoleh hasil bahwa profitabilitas dan leverage berpengaruh terhadap kebijakan dividen. Sedangkan kepemilikan manajerial, kepemilikan institusional dan likuiditas tidak berpengaruh terhadap kebijakan dividen.

Saran yang dapat diberikan bagi peneliti selanjutnya yang ingin melakukan penelitian mengenai kebijakan dividen hendaknya menambah variabel-variabel lain yang belum digunakan pada penelitian ini, seperti pertumbuhan, ukuran perusahaan.

\section{DAFTAR PUSTAKA}

Cahyanti, S. (2018). Pengaruh Rasio Keuangan dan Pertumbuhan Laba terhadap Kebijakan Dividen pada Perusahaan Manufaktur di BEI. Jurnal Penelitian Ekonomi dan Akuntansi, Volume III No. 2 hal 739-754.

Edison, A. (2017). Kepemilikan Asing, Kepemilikan Institusional dan Kepemilikan Manajerial Pengaruhnya Terhadap Luas Pengungkapan Corporate Social Responsibility CSR) (Studi Empiris Pada Perusahaan Sektor Utama Yang Terdaftar Di Bursa Efek Indonesia Tahun 2013-2014. Jurnal Bisnis Dan Manajemen Fakultas Ekonomi Universitas Widyatama, , 11(2), 164-175.

Karthik, P., \& Devanadhen, D. K. (2015). Determinants of Dividend Policy of Public and Private Commercial Banks in India : A Panel Data Approach. International Refereed Research Journal, 111-121 Vol.-VI, Issue - 3.

Kasmir. (2010). Pengantar Manajemen Keuangan. Jakarta: Kencana Prenada Media Group.

Kepemilikan Manajerial, Kepemilikan Institusional, Profitabilitas, Leverage, Likuiditas 
Kasmir. (2012). Pengantar Manajemen Keuangan. Jakarta: Kencana Prenada Media Group.

Kautsar, A. (2019). The Impact of Ownership Structure on Dividend Payout Property and Construction Companies in Indonesia. International Journal of Academic Research in Economics and Management Sciences , 8(1), 66-74.

Laily, S. (2017). Analysis on Dividend Payout :Empirical Evidence of Property Companies in Malaysia . International Journal of Industrial Management (IJIM) , 61-71 vol.3.

Lestari, K. F., Tanuatmodjo, H., \& Mayasari. (2016). Pengaruh Likuiditas dan Profitabilitas Terhadap Kebijakan Dividen. Journal of Business Management Education , 1(2), 1116.

Nurlaela, S., Mursito, B., Kustiyah, E., Istiqomah, \& Hartono, S. (2019). Asset Turnover, Capital Structure and Financial Performance Consumption Industry Company in Indonesia Stock Exchange. International Journal of Economics and Financial Issues, 297-301.

Robbins, \& Coulter. (2007). Manajemen. Jakarta: PT Indeks .

Sartono, A. (2015). Manajemen Keuangan Teori dan Aplikasi Edisi Keempat . Jogjakarta: BPFF.

Sholikhah, K. A., \& Hermanto, S. B. (2017). Pengaruh Likuiditas, Profitabilitas, Leverage, Cash Position, dan Growth Terhadap Kebijakan Dividen. Jurnal Ilmu Dan Riset Akuntansi , 6(5), 1903-1921.

Sudana, I. M. (2011). Manajemen Keuangan Perusahaan Teori dan Praktek . Jakarta: Erlangga.

Wahidahwati. (2002). Pengaruh Kepemilikan Manajerial dan Kepemilikan Institusional Pada Kebijakan Hutang Perusahaan : Sebuah Perspektif Theory Keagenan. Jurnal Riset Akuntansi Indonesia, Vol.5 No.1 hal 1-16.

Wahyuni, S. F., \& Hafiz, M. S. (2018). Pengaruh CR, DER dan ROA Terhadap DPR pada Perusahaan Manufaktur di BEI. Jurnal Ekonomi \& Ekonomi Syariah, Vol 1 No 2.

Wedyaningsih, N., Nurlaela, S., \& Titisari, K. H. (2019). Earning Pers Share, Debt to Equity Ratio, dan Current Ratio terhadap Profitabilitas Perusahaan Sub Sektor Barang Konsumsi di Indonesia. Jurnal Edunomika, 97-107.

Winanti, E., Nurlaela, S., \& Titisari, K. H. (2017). Pengaruh Rasio Likuiditas, Rasio Produktivitas, Rasio Profitabilitas dan Rasio Solvabilitas Terhadap Peringkat Sukuk . Jurnal Akuntansi dan Pajak, 130-139. 